\title{
THE MALARIA BURDEN AND AGRICULTURAL OUTPUT IN NIGERIA
}

\author{
JIMOH A. \\ DEPARTMENT OF ECONOMICS \\ UNIVERSITY OF ILORIN \\ NIGERIA
}

\begin{abstract}
Using the production function approach to quantifying a disease burden, this study evaluates the malaria burden on the Nigerian agricultural sector. Its results show that the economic burden of malaria, in terms of lost agricultural output, may be as high as $\$ 3.953$ million for every reported case of malaria per 100, 000 persons and therefore colossal. This together with evidence from other related studies suggest that the agricultural sector bears about 75 per cent of the direct economic burden of malaria in Nigeria. This translates to about 3 per cent of the real GDP that is lost annually in agricultural outputs to the malaria disease. This being the case, the government is advised to make the rural areas, where majority of farmers reside, a priority in its malaria control efforts.
\end{abstract}

Key Words: Malaria burden; Nigerian agricultural output; and malaria control efforts.

\section{INTRODUCTION}

Malaria is a serious problem in Africa (Gallup and Sachs, 2001; Shepard, et al, 1991 ) as it accounts for over 90 per cent of all cases of malaria in the world - estimated to be about $300-500$ million cases annually (World Health Organization, 1999a and 1999b). By current estimates, malaria accounts for about $80-85$ per cent of annual population morbidity in Africa (AAAS, 1991). The hardest hit among its victims are children and pregnant women. From available figures, about 2 per cent of the children who recover from cerebral malaria are estimated to suffer brain damage (WHO/UNICEF, 2003). In children, the neurological aftermaths of cerebral malaria impact negatively on their learning abilities. Also, because malaria negatively affects a child's school attendance, it limits his/her educational attainment in later life (WHO/UNICEF, 2003). When malaria is not adequately treated in pregnant women, the likely outcomes are anemia, miscarriages, underweight babies and maternal deaths (WHO/UNICEF, 2003). The total annual cost of malaria to Africa may be in excess of US\$2 billion (WHO, 1997). Thus, Africa's malaria burden, now and into the future, must be a heavy one.

Within the African region, Nigeria is known for high prevalence of malaria (Federal Ministry of Health 1992; Ejezie, et al; Leighton and Foster, 1993; Onwujekwe, et al, 2000). Malaria illness imposes great burden on the society as it has adverse effects on the physical, mental and social well being of the people as well as on the economic development of the nation. These burdens manifest in a number of ways. First, is the direct health burden of malaria by which its victims suffer physical and psychological pains and which result in either morbidity or mortality. Second, as the main consequences 
of malaria morbidity and mortality, economic activities of malaria victims and their care givers are impaired giving rise to significant loss in outputs - the economic impacts or burden of the illness.

With agriculture providing employment for over 80 per cent of the Nigerian labour force (Omotesho, et al., 1995) and responsible for about 30 per cent of the national output (Central Bank of Nigeria, CBN, 1999c), it is to be expected that the agricultural sector would bear a lion share of the economic burden of malaria in Nigeria. Thus, as Nigeria attempts to boost the output of the agricultural sector and alleviate poverty, knowledge of the size of economic burden of malaria on the agricultural sector will be helpful in determining the priority that should be accorded by government to malaria control in the rural areas where majority of the farmers reside.

Desirable as having a measure of the malaria burden on the agricultural sector is, our comprehensive review of the relevant literature cannot spot any study that provides such a measure. The aim of the current effort is to bridge this gap in our knowledge. To this end, the rest of this report consists of the following: Section 2: Choice Model and Model specification, Section 3: Empirical Results and Implications, and Section 4: Concluding Remarks.

\section{CHOICE OF MODEL AND MODEL SPECIFICATION}

In evaluating the economic burden of malaria, one of the three popular approaches to evaluating the disease burden is often adopted. These approaches are the Production Function Approach, Cost-of Illness Approach and the Willingness to Pay Approach. Both Cost-of Illness and the Willingness to Pay Approaches as of necessity rely on surveying households or some focused groups and are, therefore, micro-based (Onwujekwe, et al, 2000; Guiguende, et al, 1997). In contrast, studies concerned with evaluating overall (aggregate) economic burden of malaria on an economy/economies (or a sector therein) adopt Production Function Approach (Gallup and Sachs, 2001). Consequently, in evaluating the aggregate effects of malaria on a sector like agriculture, the Production Function Approach appears to be the tool of first choice. Thus, we follow Gallup and Sachs (2001) in adopting the Production Function Approach in our attempt to realize our objective.

\section{Model Specification}

We postulate that the real agricultural output (Y), proxied by real Agricultural Gross Domestic Product $\left(\mathrm{GDP}_{\mathrm{a}}\right)$ - Agricultural GDP at constant prices - is a positive function of Labour employed in agriculture $\left(\mathrm{L}_{\mathrm{a}}\right)$, Capital stock employed in Agriculture $\left(\mathrm{K}_{\mathrm{a}}\right)$ and a vector of other supply shocks or other factors of production $(\mathrm{S})$ :

$$
\mathrm{Y}=\mathrm{F}\left(\mathrm{L}_{\mathrm{a}}, \mathrm{K}_{\mathrm{a}}, \mathrm{S}\right)
$$

In the vector of supply shocks, we have included the index of malaria prevalence (M) to capture its impacts and guided by Jimoh (1989) we have included availability of credit, proxied by the change in the level of broad money supply $\left(\mathrm{M}_{2}\right)$. Thus, we re-write equation (1) as:

$\mathrm{Y}=\mathrm{F}\left(\mathrm{L}_{\mathrm{a}}, \mathrm{K}_{\mathrm{a}}, \mathrm{M}, \mathrm{M}_{2}, \mathrm{~S}\right)$

A priori, it is expected that as malaria attacks become more prevalent (i.e. as $\mathrm{M}$ increases), Y falls. Put more precisely,

$$
\mathrm{F}_{\mathrm{L}}>\mathrm{O}, \mathrm{F}_{\mathrm{K}}, \mathrm{F}_{\mathrm{M} 2}>\mathrm{O}, \mathrm{F}_{\mathrm{M}}<\mathrm{O} \text {, and } \mathrm{F}_{\mathrm{S}} \lesseqgtr \mathrm{O} \ldots \ldots
$$


Where $F_{X}=\frac{\partial Y}{\partial X}$

The change in money stock $\left(\mathrm{M}_{2}\right)$ is expected to measure the extent to which monetary policy can be used to stimulate agricultural output even if only in the short run when information asymmetry between producers and workers creates a positive relationship between $\mathrm{M}_{2}$ and $\mathrm{Y}_{\mathrm{a}}$. Its counterpart in fiscal policy, commonly measured by levels of government expenditures $(\mathrm{G})$, is commonly found by existing studies not to be an important determinant of the Nigerian outputs (Jimoh, 1989). This and our preliminary trial with Nigerian data inform its non-inclusion in our vectors of supply shocks in equation (2) above.

If an Error-Correction Model (ECM) is indicated, the ECM associated with equation (2) will be:

$$
\triangle \mathrm{Y}=\mathrm{F}\left(\triangle \mathrm{L}_{\mathrm{a}}, \triangle \mathrm{K}_{\mathrm{a}}, \triangle \mathrm{M}, \triangle \mathrm{M}_{2}, \triangle \mathrm{S}, \mathrm{ECM}_{\mathrm{t}-1}\right)
$$

\section{Data Measurement and Sources}

In what follows, we provide an outline of data measurement procedures and their sources, our method of estimation as well as present our empirical results and discuss their implications.

\section{Malaria Index}

The measurement of the malaria index - the focus of this study - deserves special attention. In selecting a measure of the malaria index for this study, we have been guided by the studies of Audibert (1986), Wang'ombe and Mwabu (1993), Bruce-Chwatt (1987), Brohult et al (1981), Pehrson et al (1984), Audibert et al (1999) and the critical review of existing studies by Chima et al (2003). These studies suggest that an appropriate measure must reflect the extent to which it victims have been rendered inactive or unable to perform their normal productive activities. Morbidity rate happens to be one of such measures. Thus, malaria index in this study is measured by the number of reported cases of malaria per 100,000 persons. This is expected to be a good proxy for the intensity of malaria attacks - including cases not reported - as it is expected to be order-preserving. The data on malaria index so measured was obtained from Federal Office of Statistics, F.O.S. (1970-1999), and from Epidemiology Division, Department of Public Health, Federal Ministry of Health, Abuja, (for 1991 - 1999).

\section{Labour and Capital Stock Variables}

Labour employed is measured by the total number of people employed in agriculture in Nigeria. The data for labour employed was obtained from Dike (1995; 1999) and FOS (1996; 2000). Similarly, data on capital stock in agriculture is obtained from Dikke (1995; 1999) and FOS (1996; 2000).

Data on $\mathrm{GDP}_{\mathrm{a}}$ and $\mathrm{M}_{2}$ are obtained from International Monetary Funds, IMF (IMF, 1990) and Central Bank of Nigeria (CBN) - CBN (a: various issues); CBN (b: various issues) and CBN (1999c). All the data cover the period $1970-1999$. 


\section{RESULTS AND DISCUSSION}

To be certain that our estimated regression results are not spurious, we tested for their order of integration using Augmented Dickey-Fuller (ADF) $(1979 ; 1981)$ test - the unit root test. The results of the tests are shown in Table 1 . These show that the variables are not stationary in their level forms. However, all are stationary in their first differences (integrated of order one). Thereafter, we tested for co-integration among $Y, K_{a}, L_{a}, M$, and $\mathrm{M}_{2}$ using Engle and Granger's (1987) two-step co-integration test procedure (for a non-technical guide to this procedure see Charemza and Deadman, 1992). This test on the residuals obtained after estimating equation 2 gives an ADF statistic of (-2.9008) against a MacKinnon Critical value of $(-1.9602)$ (at 5 per cent confidence level) thereby revealing that the variables are co-integrated ${ }^{1}$. Consequently, the chances that our regression results are from a spurious relationship are low. Furthermore, these results indicate that an ECM formulation is appropriate.

The aggregate production function as specified in equation (2) and its errorcorrection variant in equation (3) were estimated with the Ordinary Least Squares (OLS) technique. Two functional forms were also tried, linear and log-linear functional forms but the linear model proves to be a better representation of the data. Consequently, only estimates for the linear model are reported in Tables 2 and 3 respectively.

Table 1: Results of ADF Tests

\begin{tabular}{|l|c|l|}
\hline Variables & Level & Fist Difference \\
\hline $\mathrm{Y}$ & 0.723 & -3.131 \\
\hline $\mathrm{K}_{\mathrm{a}}$ & -0.276 & -3.499 \\
\hline $\mathrm{L}_{\mathrm{a}}$ & 0.684 & -2.856 \\
\hline $\mathrm{M}_{2}$ & -0.043 & -5.098 \\
\hline $\begin{array}{l}\text { MacKinnon Critical } \\
\text { At 5\% }\end{array}$ & -1.960 & -1.961 \\
\hline $\begin{array}{l}\text { MacKinnon Critical } \\
\text { at } 1 \%\end{array}$ & -2.697 & -2.706 \\
\hline
\end{tabular}

Table 2: $\quad$ Linear Model Estimates and the Associated Statistics (Equation 2)

\begin{tabular}{|c|c|c|}
\hline variables & coefficients & $\bar{t} \mathbf{t}-$ Values \\
\hline Constant & - & - \\
\hline Capital employed $\left(\mathrm{K}_{\mathrm{a}}\right)$ & $0.998 *$ & 4.809 \\
\hline Labour $\left(\mathrm{L}_{\mathrm{a}}\right)$ & $1672.835^{*}$ & 19.626 \\
\hline Malaria index $(\mathrm{M})$ & $-3.953 *$ & -3.622 \\
\hline $\begin{array}{l}\text { Change in Money Stock } \\
\left(\mathrm{M}_{2}\right)\end{array}$ & $0.308^{*}$ & 3.789 \\
\hline \multicolumn{3}{|c|}{$\begin{array}{l}\text { Other Statistics: } \\
\text { Adjusted } \mathrm{R}^{2}=0.744 ; \mathrm{DW}=1.920 ; \mathrm{F}=20.341 \\
\text { Notes: }(1) * \text { Implies coefficient is significant at } 5 \% \\
\quad(2) \text { - implies coefficient is not significant at } 15 \%\end{array}$} \\
\hline
\end{tabular}

${ }^{1}$. We would have double checked this result using Johnansen's(1988) co-integration test framework (see also Johansen and Juselius, 1990), but the associated Vector Autoregressive (VAR) formulation would require higher lags than could be accommodated given the number of our data points. 
From the information contained in Tables 2 and 3, both the long-run model (equation 2) and its corresponding short-run model (equation 3) have good statistical properties and have the right signs (well-behaved); virtually all the estimates are statistically significant at 5 per cent confidence level. Consequently, valid inferences can be made from them.

Table 3: $\quad$ ECM Model Estimates and the Associated Statistics (Equation 3)

\begin{tabular}{|c|c|c|}
\hline variables & coefficients & t t-Values \\
\hline Constant & - & - \\
\hline Capital employed $\left(\Delta \mathrm{K}_{\mathrm{a}}\right)$ & 0.480 & 1.660 \\
\hline Labour $\left(\Delta \mathrm{L}_{\mathrm{a}}\right)$ & 6932.039* & 2.949 \\
\hline Malaria index $(\Delta \mathrm{M})$ & $-2.078 *$ & -2.875 \\
\hline $\begin{array}{l}\text { Change in Money Stock } \\
\left(\Delta \mathrm{M}_{2)}\right.\end{array}$ & $0.205^{*}$ & 4.194 \\
\hline $\mathrm{ECM}_{\mathrm{t}-1}$ & $-0.721 *$ & -3.516 \\
\hline \multicolumn{3}{|c|}{$\begin{array}{l}\text { Other Statistics: } \\
\text { Adjusted } \mathrm{R}^{2}=0.715 ; \mathrm{DW}=1.830 ; \mathrm{F}=12.932 . \\
\text { Notes: }(1) * \text { Implies coefficient is significant at } 5 \% \\
\quad(2) \text { - implies coefficient is not significant at } 15 \%\end{array}$} \\
\hline
\end{tabular}

\section{Implications}

From these results, it is clear that the economic burden of malaria in terms of lost agricultural output is colossal. For instance, from Table 2, for every one reported case of malaria per 100, 000 persons, the loss in real output is about $\$ 3.953$ million. This should not be surprising because for every reported case probably as many as 99 others are not reported. Thus, a reported case may be a proxy for as many as 100 cases. Further, for each malaria case - reported or not - one other person is held down to cater for the sick. Consequently, a reported case may be a proxy for as many as 200 persons whose outputs are lost. Similarly, the coefficient of labour in Table 2, suggests that an increase of about one million in the number of persons employed in agriculture would result in an increase in agricultural output of about $\mathrm{N} 1.673$ billion. This translates to a marginal productivity of about N 1,673 per annum for labour and confirms the low income level that is often associated to peasant agriculture in a Less Developed Country (LDC) like Nigeria.

In a similar vein, the coefficient of capital stock in Table 2 suggests that a one million Naira increase in agricultural capital stock (in constant prices) leads to about a million Naira increase in agricultural output measured in constant prices. Furthermore, it suggests that a unit increase in money supply would stimulate agricultural output by about N 0.308 .

The short-run estimates reported in Table 3 leads to conclusions similar to those derivable from Table 1. For instance, from Table 3, for every one reported case of malaria per 100, 000 persons, the loss in real output in the short run is about 2.078 million which is smaller than the long-run adverse effect of N3.953 million; this short-run effect is gradually, through an error-correction process, adjusted to its long-run value. On the contrary, Table 3 suggests the impact effect of an increase in the number of persons 
employed in agriculture would be larger than that of the long-run ( $\mathrm{N} \mathrm{6,932} \mathrm{against}$ N1,673).

In a similar vein, the coefficient of capital stock in Table 3 suggests that short-run effect of an increase in agricultural capital stock is lower ( and indeed insignificant) than its effect in the $\log$ run (which is significant) - N0.480 against N0.998. Finally, the impact effect of expansionary monetary stance is lower in the short than in the long run N0.205 against N0.308.

All these together with the findings of Jimoh (2003) in a larger but related study, that puts the direct malaria burden to the Nigerian economy at about 4 per cent of the real GDP, suggest that the agricultural sector bears about 75 per cent of the direct economic burden of malaria in Nigeria. This translates to about 3 per cent of the annual real GDP of Nigeria that is lost to the malaria disease. This being the case, the government is advised to make the rural areas, where majority of farmers reside, a priority in its malaria control efforts.

From these results, it is clear that the economic burden of malaria in terms of lost agricultural output is colossal. This study suggests that for every one reported case of malaria per 100, 000 persons, the loss in agricultural output could be as high as $\$ 3.953$ million. Noting that for every reported case, many others are not reported and that additional one other person is held down to cater for the sick, it is not unlikely that a reported case may be a proxy for as many as 200 persons whose outputs are lost.

The findings of this study together with evidence from other related studies suggest that the agricultural sector bears about 75 per cent of the economic burden of malaria in Nigeria. This being the case, the government is advised to make the rural areas, where majority of farmers reside, a priority in its malaria control efforts.

\section{REFERENCES}

American Association for the Advancement of Science (AAAS) (1991), Malaria and Development in Africa: A Cross-Sectoral Approach, AAAS, Washington, DC.

Audibert, M. (1986), "Agricultural Non-wage Production and Health-Status - A Case Study in a Tropical Environment", Journal of Development Economics, 24(2): 275-291.

Audibert, M., Mathonnat J., Nzeyimana I., and M. Henry (1999), "Le role du Paludisme dans L'efficience Technique de Producteurs de Contonde nord de la Cote D'Ivoire", Revue D'Economie du Development, 4: 121-148.

Brohult, J., L. Jorfeldt L., L. Rombo, Bjorkman A., Pehrson P., Birleaf V. and E. Bengtbbon (1981), "The Working Capacity of Liberian Males: A Comparison between Urban and Rural Populations in Relation to Malaria", Annals of Tropical Medicine and Parasitology, 75(5): 487-494.

Bruce-Chwalt, L.J. (1987), "Malaria and its Control - Present Situation and Future Prospects", Annual Reviews of Public Health, 8: 75-110.

Central Bank of Nigeria (CBN) (a: various issues), Annual Reports and Statement of Accounts, CBN.

Central Bank of Nigeria (CBN) (b: various issues), Statistical Bulletin, CBN.

Central Bank of Nigeria (CBN) (1999c), Statistical Bulletin, CBN, 10 (1).

Charemza, W. W. and Deadman D. F. (1992), New Directions in Econometric Practice, Edward Elgar Publishing Limited, Brookfield, Pp. 117 - 159. 
Chima, R. I., Goodman C. A. and Mills A. (2003), "The Economic Impact of Malaria in Africa: a Critical Review Evidence", Health Policy, 63(1): 17-36.

Dickey, D. A. and Fuller W. A. (1979), "Distribution of the Estimator for Autoregressive Time Series with a Unit Root", Journal of the American Statistical Association, 79: 427-431.

Dickey, D. A. and Fuller W. A. (1981), "Likelihood Ratio statistics for Autoregressive Time Series with a Unit Root", Econometrica, 49: 1057-1072.

Dike, E. (1995), "Structural Adjustment and Inter-sectoral Resource Allocation: A Case Study of Investment and Labour Flows in Nigeria Agriculture", CODESRIA Research Report, Senegal, October.

Dike, E. (1999), "Explaining Investment Allocation to Agriculture in Nigeria: Beyond the Domestic Terms Trade (DTT) Hypothesis", Nigerian Journal of Economic and Social Studies, 41 (2): 295 -314.

Ejezie, G. C., Ezednachi E. N., Usanga E. A., Gemade E. I., Ikpatt N. W. and Alaribe A. A. (1991), Malaria and its treatment in rural villages of Aboh Mbaise, Imo State Nigeria. Acta Tropica, 48: 17 - 24

Engle, R. and Granger C. (1987), "Co-integration and Error Correction: Representation, Estimation and testing", Econometrica, 55: $251-276$.

Federal Ministry of Health (, 1992), The National Health Policy of Nigeria, Federal Ministry of Health, Lagos.

Federal Ministry of Health (2001), Strategic Plan for Rolling back malaria in Nigeria 2001 - 2005, Abuja, FMOH.

Federal Office of Statistics (FOS) (1970 - 1999), Annual Abstract of Statistics, FGN, Abuja.

FOS, Socio-Economic Profile of Nigeria, FOS, 1996.

FOS, General Household Survey, FOS, June, 2000.

Gallup, J.L., and Sachs, J.D. (2001), "The Economic Burden of Malaria", The American Society of Tropical Medicine and Hygiene, pp. $85-96$.

Guiguemde, T. R., Coullibaly S. O., Ouedraogo J. B. and Gbary A. R. (1997), “An outline of a method for estimating the calculated economic cost of malaria cases: its application to a rural area in Burkina Faso (Western Africa)", Tropical Medicine and International Health, 2(7): 646-653.

International Monetary Fund (IMF) (1990), International Financial Statistics Year Book, IMF, Washington, D.C.

Jimoh, A. (1989), "The Role of Exchange Rate Policies in the Management of the Nigerian External Balance", Nigerian Financial Review, 2 (1): 35 - 48.

Jimoh, A. (2003), “The Economic Burden of Malaria: Evidence from Nigeria (1)”, A Technical Report for World Health Organization (WHO), April.

Johansen, S. (1988), "Statistical Analysis of Co-integration Vectors", Journal of Economic Dynamics and Control, 12: 231-254.

Johansen, S., and Juselius, K. (1990), "Maximum Likelihood Estimation and Inference on Co-integration - with Application to Demand for Money", Oxford Bulletin of Economics and Statistics, 52: 169-210.

Leighton C and Foster R. (1993), "Economic impacts of malaria in Kenya and Nigeria", Health Financing and Sustainability Project 6, Bethesda, Abt Associates, Maryland. 
Omotesho, O. A., Adewumi M. O. and Ajayi A. A. (1995), "Labour Utilization in Peasant Agriculture: A Survey of Four Local Government Areas of Kwara State, Nigeria" Centre Point Science Edition, 5(1): 77-99

Onwujekwe, O., R. Chima and Okonkwo P. (2000), "Economic Burden of Malaria Illness on Households Versus That of All Other Illness Episodes: A Study in Five Malaria Holo-endemic Nigerian Communities", Health Policy, 54: 143 - 159.

Pehrson, P.O., Brohult, J., L. Jorfeldt L., L. Rombo, A. Bjorkman, V. Birleaf and E. Bengtbbon et al. (1984), "Is the Working Capacity of Liberian Industrial Workers Increased by Regular Malaria Prophylaxis", Annals of Tropical Medicine and Parasitology, 78(5): 453-458.

Shepard, D. S., Brinkmann U., Ettling M. and Sauerborn R. (1991), "The economic cost of malaria in Africa", Tropical Medicine and Parasitology, 42 (3): 199-203.

Wang'ombe, J.K. and Mwabu G.M. (1993), "Agricultural Land Use Patterns and Malaria Conditions in Kenya", Social Science and Medicine, 37(9), Pp. 275-291.

WHO/UNICEF (2003), Africa Malaria Report, WHO/CDS/MAL/2003.1093.

World Health Organization (WHO) (1999b), World Health Report, 1999: Making a Difference, http:/www.who.int/whr/1999.

World Health Organization (WHO) (1999a), "Malaria 1982 - 1997", Weekly Epidemiological Record, 94: 265 - 270.

World Health Organization (WHO) (1997), "World Malaria Situation in 1994", Weekly Epidemiological Record, 36: 269-274. 